\title{
RESENHA
}

\section{Um estudo sobre o estado de exceção brasileiro}

\author{
VALIM, Rafael. Estado de exceção: a forma jurídica \\ do neoliberalismo. São Paulo: Contracorrente, \\ 2017.
}

\author{
Débora Maria Martins \\ Universidade Federal do Ceará, Brasil \\ iD https://orcid.org/0000-0002-3449-7188 \\ deboramariamartins123@gmail.com
}

A obra Estado de exceção: a forma jurídica do neoliberalismo é produto da observação constante, pelo autor, da atualidade brasileira, em que se encontra presente o generalizado desrespeito ao mais importante documento político-jurídico do país: a Constituição, a qual é desconsiderada no exercício de diversas instituições.

$\mathrm{O}$ autor tenta mostrar, nessa pesquisa, que o autoritarismo se encontra cada vez mais presente no Brasil, indo de encontro ao Estado democrático de Direito. Uma ilustração trazida consiste no fato de ser cada vez mais recorrente, nos debates e pronunciamentos públicos, a tortura, com um discurso que a legitima e a defende. Entretanto, 
a garantia dos direitos individuais, entre eles, a dignidade da pessoa humana, é cláusula pétrea na Constituição. Por isso, esse tema não deveria ser defendido em debates e pronunciamentos públicos. Porém, o estado de exceção afasta as garantias do Estado de direito, legitimando discursos como esse exemplificado (VALIM, 2017, p. 28).

A deslealdade a Constituição e as outras leis do país acontecem decididas não mais pelos representantes eleitos, e sim pelo capital financeiro (VALIM, 2017, p. 29). Diante disso, pode-se fazer a comparação, pela semelhança dos assuntos trabalhados, embora em obras diferentes e não relacionadas de forma direta, do apontamento de Valim com o de Bobbio (1986, p. 29-30), que traz o conceito de poder invisível, o qual a democracia, em seu projeto, ao afirmar que o povo seria a maior força de poder, prometeu excluir, mas que ganha cada vez mais força e influência.

Da mesma forma, pode-se relacionar, nessa atual pesquisa, o que é trabalhado na obra de Valim com as conclusões do estudo de Milton Santos (2010, p. 68-69), com o exemplo prático, embora não trazido no livro resenhado, da relevância do capital financeiro: hoje, as empresas de grande porte, ao adentrarem e se instalarem em determinado local, são tratadas como salvadoras, uma vez que trarão novas oportunidades de emprego e de modernidade. Nasce, diante disso, uma ideia de indispensabilidade dessas empresas. A adversidade desse fato é que isso ocasiona, muitas vezes, brigas entre territórios para instalação da empresa e chantagem diante do Estado, que afirma que pode ir embora, levando toda a oportunidade de emprego, caso suas solicitações não sejam atendidas. O poder público, então, fica cada vez mais sujeito às empresas. Com uma possível chantagem diante do poder público, este passa a dar importância as reivindicações das empresas de grande porte, na tentativa de fazer que elas permaneçam no seu 
território, e deixa em segundo plano o interesse geral, abandonando seu caráter social e solidário.

Sob essa ótica, é relevante, também, o destaque da influência da globalização e do neoliberalismo diante da linguagem, a partir de apontamento em obra divergente da resenhada no atual trabalho e não trazido por ela. Para isso, é necessário a diferenciação de dois conceitos: nação ativa e passiva.

Nação ativa se mostra como aquela que obedece, de forma cega e ilimitada, a vontade globalitária. Obedece a ordens das burguesias internacionais e nacionais associadas a estas. Traz, em seu conceitobase, a ideologia das ideias de riqueza e a produção da conformidade (em que não se aceita mais discussão diante do sistema e, em caso de desobediência, os agentes são expulsos). Nação passiva é aquela formada majoritariamente pela população e pela economia que participam do sistema e da ideologia dominante. Aceitam, então, a insatisfação e o inconformismo dos agentes diante do sistema e dos seus resultados. Ainda é marcada pelo seu território, ainda é enraizada no seu local. Entretanto, o cerne da questão é que não é propositado tais definições relativas a essas expressões. "Ou aquilo a que, desse modo, se está chamando de nação ativa seria, na realidade, a nação passiva, enquanto a nação chamada passiva seria, de fato, a nação ativa?”. (SANTOS, 2010, p. 156-157).

Ademais, esse poder do mercado na democracia torna esse regime de governo vazio, uma vez que não busca resolver os conflitos sociais (VALIM, 2017, p. 33). É inevitável, ao leitor dominante do assunto, diante da abordagem do autor trabalhada em sua obra, a comparação, por juízo de valor, com o pensamento de dois autores. O primeiro escritor é Bobbio (1986, p. 139-143), o qual afirma que o público se transforma cada vez mais privado, uma vez que aqueles capazes de 
votar, ou seja, de escolher seus representantes, não se tornam mais eleitores, e sim clientes de um mercado político. O eleito deve ser o empresário, que gere a máquina chamada Estado, e o eleitor deve ser um negociador, para que aquele que está acima possa satisfazer suas finalidades. O segundo escritor é Milton Santos (2010, p. 54), que acredita que surge o fenômeno chamado eleitoralismo, o qual não possui o debate efetivo e o enriquecimento de ideias no processo eleitoral.

Nesse período peculiar da história do Brasil que se vive, várias instituições legitimam o problema do estado de exceção. Entre elas, o Poder Executivo, ao ser polícia administrativa, e o Judiciário (VALIM, 2017, p. 36).

Muitos foram os autores que estudaram a origem e as características do estado de exceção, como o Agamben e Schmitt. Contudo, Valim trabalha essa realidade no Brasil, de forma expressa, no capítulo terceiro. Essa situação se expressa claramente no país nas sentenças excepcionais, que vão de encontro com a legislação brasileira, tomadas por juízes que afirmam que as assinam no falso objetivo de combater a corrupção (VALIM, 2017, p. 16). Pode-se enquadrar, por juízo de valor, a partir da leitura da obra, a situação explicada pelo escritor com um caso recente, embora ocorrido em momento posterior ao da publicação do livro: o ex-presidente Lula não teve permitida a saída da prisão, pelo Judiciário, para o velório do seu irmão, um direito garantido ao preso na Lei de Execução Penal e que é decidido não por juízes, e sim pelo diretor do presídio. De forma controversa, quando o mesmo indivíduo se encontrou preso durante a ditadura militar, um regime autoritário, ele pode sair para comparecer ao enterro de sua mãe.

Destarte,

Persiste uma sociedade[brasileira] profundamente autoritária, hos- 
til aos mais elementares avanços em termos de direitos humanos, o que, naturalmente, explica a facilidade com que a exceção não só é assimilada, como também dissimulada em seu seio. (VALIM, 2017, p. 40).

Assim, o desrespeito aos direitos individuais e coletivos são proclamados por juízes, arbitrariamente, os quais passam a ser considerados como "salvadores de pátria”. "Não é mais a voz do povo, plasmada na Constituição Federal e nas leis, senão uma insondável”voz das ruas”". (VALIM, 2017, p. 46).

A obra de Valim é uma leitura de muita relevância no atual momento brasileiro, por trazer conhecimento de outros estudiosos que trabalham com a situação de exceção semelhante em outros países que aconteceram anteriormente e combinar isso com a atual situação do país, trazendo exemplos práticos. Entretanto, a indispensabilidade desse trabalho não se mostra importante apenas para a realidade brasileira. Isso acontece porque, embora de suma importância o trabalho desses outros estudiosos, como Agamben e Schmitt, a pesquisa realizada é focada, majoritariamente, na realidade europeia, a qual, por possuir expressão histórica e política divergente da realidade brasileira, também expressa o neoliberalismo de forma diferenciada. Assim, a obra aqui resenhada se mostra primordial ao trazer o estudo do Estado de Exceção em uma realidade sul-americana, com aplicabilidade divergente, embora pertinentes algumas características, do estudo do neoliberalismo, mostrando-se, assim, primordial para a visão das ciências sociais brasileira e latina como um todo.

Pode-se perceber que as raízes do autoritarismo brasileiro já se encontravam no país há um tempo, uma vez que Milton Santos, como anteriormente citado, traz bases para as afirmações de Valim na obra. O autor, então, trabalha as consequências de todo esse enraizamento de ideias autoritárias no Brasil da atualidade. 


\section{Referências}

BOBBIO, Norberto. O futuro da democracia: uma defesa das regras do jogo. Tradução Marco Aurélio Nogueira. 6. ed. Rio de Janeiro: Paz e Terra, 1986. SANTOS, Milton. Por uma outra globalização: do pensamento único à consciência universal. 19 ed. Rio de Janeiro: Record, 2010.

VALIM, Rafael. Estado de exceção: a forma jurídica do neoliberalismo. São Paulo: Contracorrente, 2017. 
Recebido para publicação em 05/02/2019.

Aceito em 25/02/2020.

Revista de Ciências Sociais. Fortaleza, v. 51, n. 1, mar./jun., 2020, p. 399-405. 